\author{
Katarzyna Mroczkowska-Brand (iD) https://orcid.org/0000-0003-4590-5578 \\ Uniwersytet Jagielloński \\ katarzyna.mroczkowska-brand@uj.edu.pl
}

\title{
Postkolonialna lekcja uważności
}

\section{Lessons in Postcolonial Awareness}

\begin{abstract}
A special focus on the consequences of colonialism, what the author calls postcolonial awareness, is required because of the importance and timeliness of this legacy in the contemporary world. Postcolonial literature is tasked in this context with recording the traces of cultures either disappearing or already lost due to the actions of colonizing powers. The author discusses examples of literary texts that fulfill this function through various forms of narration and imaging. In the novel Tracks by Louise Erdrich we find an approximation of the way of life of the Chippewas, before they were confined in reserves, in the narrative of Nanapush which is addressed to his granddaughter. In the text of the Cameroonian writer Leonora Miano, La saison de lombre, we can "listen" to voices that record the experience of being abducted and taken into slavery. Richard Flanagan, in turn, recalls the traumatic experience of the loss of life, land, and culture during the colonial genocide in Tasmania, and one of the last testimonies relating to these experiences is that of an Aboriginal girl, one of the heroines of the novel Wanting.
\end{abstract}

Keywords: postcolonial literature, awareness, recording traces, memory, lost cultures, reconstruction

Streszczenie: Szczególne skupienie na konsekwencjach kolonializmu, czyli to, co autorka nazywa uważnością postkolonialną, jest potrzebne ze względu na znaczenie i aktualność tej spuścizny w otaczającej nas rzeczywistości. Literatura postkolonialna ma w tym kontekście za zadanie zapisywać ślady kultur ginących lub już utraconych na skutek działań kolonizatorów. Autorka omawia przykłady tekstów literackich spełniających tę funkcję poprzez różne formy narracji i obrazowania. Przybliżenie sposobu życia Indian Chippewa, zanim zamknięto ich w rezerwatach, znajdujemy w narracji Nanapusha skierowanej do jego wnuczki, która znalazła się w powieści Tracks Louise Erdrich. W tekście kameruńskiej pisarki Leonory Miano La saison de l’ombre możemy „odsłuchać” głosy rejestrujące doświadczenie porwania w niewolnictwo oraz przewiezienia na inny kontynent. Richard Flanagan przywołuje traumatyczne doświadczenie utraty życia, ziemi, kultury w czasie kolonialnego ludobójstwa na Tasmanii, a jedną z ostatnich relacjonujących te doświadczenia jest dziewczynka aborygeńska, bohaterka powieści Pragnienie.

Słowa kluczowe: literatura postkolonialna, uważność, zapisywanie śladów, pamięć, kultury utracone, rekonstrukcja 
So what do we do about colonialism, Other than understand it? Shashi Tharoor, The Inglorious Empire

„Uważność” jest modnym terminem wśród publicystów zajmujących się stylem życia i zdrowiem. Nie wszystkie modne terminy są niemądre czy powierzchowne, ten właśnie wydaje mi się na tyle wartościowy, że pozwolę go sobie pożyczyć do rozważań natury kulturoznawczej i literaturoznawczej, a konkretnie do problematyki postkolonialnej. W tym kontekście moja robocza definicja uważności określałaby ją jako szczególne skupienie na postrzeganiu takich znaków, śladów, zjawisk, obecnych w otaczającej nas rzeczywistości, które są konsekwencjami kolonializmu wprost lub są pośrednio z nim powiązane.

Jeśli chcemy dobrze, a więc mądrze, poznać i zrozumieć, choćby częściowo, zarówno historię, jak i dzień współczesny otaczającego świata, nie może w naszych badaniach, w naszym oglądzie, zabraknąć historii kolonializmu. Jest to potrzebne zatem do poszerzenia naszej indywidualnej wiedzy, ale gdy patrzy się z perspektywy społeczeństw, wspólnot, można stwierdzić, że brak uważności postkolonialnej może pogłębiać wiele kryzysów światowych: ekonomicznych, kulturowych i tożsamościowych.

Chciałabym w niniejszym eseju przedstawić parę ważnych argumentów świadczących o potrzebie lepszego poznania konsekwencji kolonializmu. Najpierw przypomnę fundamentalne, a mimo to często zapoznane, przykłady działań sił ${ }^{1}$ rabujących i dominujących obce terytoria, a potem chciałabym zwrócić uwagę na ślady tych działań w literaturze postkolonialnej, powstałej w obecnie ciągle trwającej i obfitującej w bardzo ciekawe dzieła epoce nazwanej przez Billa Ashcrofta czasem, kiedy „The Empire Writes Back” [„Imperium oddaje ciosem literatury” lub „Imperium odpisuje literackim ciosem”, tłum. moje - K.M.B. ${ }^{2}$.

${ }^{1}$ Używam tego słowa, bo nie zawsze były to państwa, choć najczęściej posiadały wsparcie rządowe. Na przykład angielskie działania kolonialne w Indii zaczęły się od pozornie niewinnych interwencji East India Company, założonej w Londynie już w 1600 roku. Chciałabym też wyjaśnić, że w moim szkicu skupiam się na kolonializmie, za który odpowiedzialne były rządy państw zachodnich (Hiszpania, Anglia, Holandia, Portugalia, Francja lub towarzystwa handlowe przez te państwa wspierane), ale jestem świadoma, że można mówić też o formach kolonializmu praktykowanego przez mocarstwa wschodnie - rosyjskie, otomańskie, i dalej aż po japońskie, ale ograniczam się w tym tekście do literatury postkolonialnej powstałej na obszarach podległych królestwom i imperiom zachodnim.

${ }^{2}$ Bill Ashcroft stworzył świetną grę słowną, która przyjęła się już, a odnosi się do pisania o epoce postkolonialnej w ogóle. Przerobił angielski idiom „to strike back”, oddać cios za cios, wpisując „writes” w miejsce „strikes”, łapiąc językowo dwie sroki za ogon. Rezultat to: pisarze należący do byłych kolonii piszą swoją literaturę, która uderza literackim ciosem w byłych kolonizatorów. Bill Ashcroft wprowadził ten zwrot jako tytuł książki, której był współautorem. Zob. B. Ashcroft, G. Griffiths, H. Tiffin, The Empire Wrties Back. Theory and Practice in Post-Colonial Literatures, London-New York 1989. 


\section{Upiory kolonializmu we współczesnym świecie}

Moje rozważania będą dotyczyć przede wszystkim rezultatów działań kolonialnych tych byłych imperiów (niezależnie od tego, czy formalnie takimi się nazywały, czy były nazywane), które najbardziej przyczyniły się do przepaści między żyjącymi w wielkim bogactwie albo mniej lub bardziej dostatnio, a tymi, którzy egzystują na granicy ubóstwa lub nędzy i śmiertelnego zagrożenia życia. Nie tylko skutki ekonomiczne, ale także społeczne i psychologiczne kolonialnych podbojów były i są istotne przy nakreśleniu stanu chorobowego dzisiejszych społeczeństw, również jeśli chodzi o zaburzenia tożsamości, zwłaszcza w takim sensie, w jakim więź tożsamościowa wspólnoty daje choćby minimalne poczucie bezpieczeństwa i więzi międzyludzkich. Do skutków psychologicznych kolonializmu należy też powstanie po stronie skolonizowanych syndromu ofiary, który utrzymuje się dalej, mimo uzyskania formalnej niepodległości przez dany kraj. Mieszkańcy byłych kolonii często charakteryzują się pasywnością, brakiem wiary we własne możliwości, ciągle widzą siebie jako wyłącznie pokrzywdzonych i mają wielkie trudności, by wyjść z błędnego koła biedy, nie tylko z powodów obiektywnych, ekonomicznych czy politycznych ${ }^{3}$. Naszkicowanie choć przykładowo złożoności kontekstów dominacji kolonialnej i jej konsekwencji po obu stronach konfliktu jest potrzebne, żeby pokazać obraz tych zjawisk w literaturze zwanej postkolonialną.

Jak wyraził się Shashi Tharoor, autor książki Inglorious Empire. What the British Did to India (2016) ${ }^{4}$, w bardzo trafnie zatytułowanym rozdziale The Messy Afterlife of Colonialism, jedną z nielicznych pożytecznych rzeczy, jakie możemy zrobić z dziedzictwem ery kolonialnej, jest próba zrozumienia, lepszego poznania jego historii, zwłaszcza, jeśli nie chcemy, żeby stan choroby postkolonialnej się pogłębił.

Przede wszystkim, u progu nowego tysiąclecia, spójrzmy w lusterko wsteczne, pokazujące, jak przebiegały procesy kolonizowania, choćby w największym skrócie czy wręcz hasłowo, ale mocno. Ponieważ żyjemy w świecie silnie zależnym od sloganów medialnych, zaproponujmy „uważność postkolonialną” jako jedno z haseł na 2020 rok. „History belongs to the past, but understanding it is the duty of the present (...) and in hoping to recognize possible

${ }^{3}$ O problemach, jakie stwarza syndrom ofiary, pisze Alain Mabanckou, który poświęca temu całą książkę Le sanglot de l'homme noir (Paris 2012). Nawiązuje do tej kwestii Leonora Miano w bardzo odważnym i mocnym tekście - zob. taż, Sub-Saharan Literatures and the Conquest of the Self, „Journal of the African Literature Association” 2014, t. 8 (2). W jakimś stopniu pokazuje ten syndrom Mia Couto, mozambicki pisarz, w Ostatnim locie flaminga (tłum. E. Milewska, Warszawa 2005), a sporo na ten temat znajdziemy też u wielu pisarzy karaibskich, szczególnie haitańskich.

${ }^{4}$ Sh. Tharoor, Inglorious Empire. What the British Did to India, London 2016. 
future conflict in the new millennium, we have to realize that sometimes the best crystal ball is a rear view mirror"s.

Do najpoważniejszych problemów współczesnego świata należą: nadchodząca w o wiele szybszym, niż obliczano, tempie katastrofa ekologiczna, skrajne ubóstwo ogromnej części populacji globu i powiązane z jednym i drugim masowe migracje ludzi bezrobotnych i wykorzenionych. U samego źródła tej zaistniałej patologii odnajdujemy kolonializm puszczony w ruch ponad wszelką miarę i bez adekwatnej kontroli, wspomagany siłami kapitalizmu i wolnego rynku, a zasilany odwieczną ludzką pazernością w połączeniu z mechanizmami globalizacyjnymi ${ }^{6}$.

Przywołam jeden przykład, który powinien pomóc unaocznić nam, jak kluczowy i sprawczy był kolonializm w procesie powstawania wyżej wymienionych patologii, w szczególności skali nierówności ekonomicznych i tempa bogacenia się kosztem najbiedniejszych.

Liverpool, zanim Anglia zaczęła czerpać zyski z tak zwanego triangular trade ${ }^{7}$, był osadą rybacką. Kiedy rzeka bogactw uzyskanych w rezultacie połączenia handlu niewolnikami i kolonialnej gospodarki rabunkowej zaczęła płynąć, Liverpool zmienił się błyskawicznie. "The slave trade transformed Liverpool from a fishing village into a great center of international commerce" pisze Eric Williams ${ }^{8}$, podając także, oprócz mnóstwa bardzo dokładnych wyliczeń dotyczących kosztów i zysków związanych z działalnością brytyjskich kolonialistów, podobne przykłady niezwykłych metamorfoz miast francuskich, takich jak Bordeaux czy Nantes. Oczywiście jeden przykład jest tylko kroplą w morzu, ale często na przybliżeniu szczegółu widać w zarodku początek potężnego procesu. Chodzi mi o zasygnalizowanie faktu, że to system kolonialny wprowadził przepaść między bogatymi a biednymi. Oczywiście przepaść ta

5 Tamże, s. 235, 248.

${ }^{6}$ Bardzo trafnie przypomina o powiązaniu kolonializmu z kapitalizmem Susan Buck-Morss w książce Hegel, Haiti i historia uniwersalna, tłum. K. Bojarska, Warszawa 2014: „Wyobrażając sobie, że nowoczesność jest równoznaczna z Europą, nie dostrzegaliśmy, w jakim stopniu nowoczesny kapitalizm był wytworem systemu kolonialnego, który pod wieloma względami wyprzedzał system europejski”, tamże, s. 113.

7 Traingular trade (handel trójstronny) można skrótowo opisać w sposób następujący: statki angielskie wyruszają na wybrzeże zachodnie Afryki, wioząc niepotrzebne w Anglii tandetne towary, które przeznaczono na złom, więc nic nie kosztują, w Afryce są wymieniane na pojmanych tam mieszkańców (pierwszy bok trójkąta); statki przepływają Atlantyk i lądują na posiadłościach kolonialnych Brytyjczyków, na przykład na Jamajce, gdzie przywiezieni niewolnicy jako darmowa siła robocza produkują cukier, tytoń, rum etc. (drugi bok trójkąta); statki załadowane poszukiwanymi w Anglii towarami żeglują do Londynu, Liverpoolu i innych portów, gdzie sprzedane przynoszą fenomenalne zyski, z minimalnymi kosztami ich uzyskania (trzeci bok trójkąta). Trójkąt się zamyka. Więcej na ten temat: E. Williams, From Columbus to Castro. The History of the Caribbean, London 1970; J.T. Campbell, Middle Passages. African American Journeys to Africa, 1787-2005, London 2006.

8 E. Williams, dz. cyt., s. 149. 
istniała zawsze i zapewne zawsze istnieć będzie, ale chodzi o skalę. Kolonializm, wspomagany niewolnictwem i wstępnymi formami kapitalizmu, a przeobrażony przez rewolucję technologiczną w najbardziej drapieżną odmianę, pogłębił ten rów na taką skalę, że osiągnięto "the point of no return” (czyli dotarto do „miejsca, z którego nie ma powrotu”) 9 .

System kolonialny pogłębił także przepaść pogardy. Przekonanie o swojej wyższości, tak rozpowszechnione wśród kolonialistów, niezależnie od tego, czy owo poczucie opierało się na religii, bogactwie, pochodzeniu rasowym czy jeszcze innych czynnikach, było toksyczne i destrukcyjne przede wszystkim dla pogardzanych, a na dłuższą metę też samych pogardzających, w stopniu porównywalnym z niszczącym rezultatem - obrabowaniem kolonizowanych i wtrąceniem ich w skrajną biedę.

Przepaść pogardy była, może jeszcze bardziej niż przepaść biedy, katastrofalna w skutkach wielopokoleniowych. Obraz tego zjawiska znajdziemy w bardzo wielu utworach literackich, szczególnie w świetnie nadających się do tego rozbudowanych powieściach-sagach, osadzonych w kontekstach kolonialnych. Mistrzyniami takiej powieści, o czym za chwilę, są między innymi Toni Morrison i Louise Erdrich, Afroamerykanka i Amerykanka pochodzenia indiańskiego. Ale zanim o literackim obrazowaniu będzie mowa, przytoczę jeszcze opinię historyka, autora The Inglorious Empire, ilustrującego problem skutków pogardy i braku szacunku dla kolonizowanych. Często u zdominowanych objawia się to poczuciem braku szacunku dla samych siebie, a oto cytaty: „We have given you everything here in India! What is it you don't have - asked the Prince of Wales, the future Edward VIII. - Self-respect, sir - replied the lowly Indian gently"10.

Drugi cytat dotyczy momentu, w którym sir Rabindranath Tagore zdecydował się oddać swój tytuł „knighthood”, nadany przez monarchę brytyjskiego, gdyż: „he did not want a "badge of honour « in the context of humiliation”"11. Warto też zwrócić uwagę na tragiczną ironię, która zabarwiała stosunek Anglików do Hindusów, reprezentujących starożytne bogactwo kultury, górującej nad tą, którą prezentowali sobą, zwłaszcza wówczas, Brytyjczycy ${ }^{12}$.

${ }^{9}$ Badaczy, którzy podpisują się pod taką hipotezą, jest wielu, ja powołuję się w szczególności na autorów wyżej wymienionych książek, takich jak E. Williams, S. Buck-Morss, J.T. Campbell.

${ }^{10}$ Sh. Tharoor, dz. cyt., s. 225.

${ }_{11}$ Tamże, s. 77.

${ }^{12}$ A oto jak nazwał podporządkowanie sobie Indii przez Brytyjczyków Will Durant w klasycznym już tekście The Case for India: „The British conquest of India was the invasion and destruction of a high civilization by a trading company (The British East India Company), utterly without scruple or principle, careless of art and greedy of gain, overrunning with fire and sword a country temporarily disordered and helpless, bribing and murdering, annexing and stealing, and beginning that career of illegal and "legal "plunder which has now (1930) gone on ruthlessly for one hundred and seventy-three years" (tenże, A Case for India, New York 1930, s. 7). 
Analogiczny przykład ogromnej dysproporcji w poziomach kultury połączonej z pogardą i stosowaniem przemocy wobec słabszego fizycznie, a wyżej stojącego kulturowo znajdziemy w literackim obrazie przedstawionym w powieści Tuba $i$ znaczenie nocy Szahrnusz Parsipur ${ }^{13}$. Upokorzonym jest w tym wypadku stary perski mędrzec, który podczas przechodzenia na drugą stronę ulicy został uderzony szpicrutą w twarz, niejako spoliczkowany, przez pędzącego konno oficera francuskiego, zirytowanego, że Pers nie ustąpił mu drogi. Ciekawe, że Francuz zostaje wzięty za Anglika, gdyż na tym terenie Brytyjczycy mieli już o wiele gorszą opinię jako pełni pychy kolonizatorzy.

W powieści irańskiej pisarki, stanowiącej bardzo ciekawy przykład literatury postkolonialnej, wyeksponowany został ten incydent, nie tyle jako rażący przykład pogardy i przemocy wobec sędziwego człowieka (oczywiście ten aspekt też jest zasygnalizowany), ile jako zdarzenie zapamiętane przez członków rodziny pokrzywdzonego i przekazywane z pokolenia na pokolenie (opowiada o tym prawnuczka), jako symbol zniewagi, naruszenia godności i honoru ludzi z kultury ceniącej tenże honor i godność ponad wszystko przez tych, którzy mienili się niosącymi wyższą cywilizację. Mechanizmy puszczone w ruch z początkiem kolonializmu były tak złożone i wielorakie, że nie sposób tutaj nawet bardzo skrótowo je przedstawić. Jest to zresztą zadanie dla historyków, a dokładniej, do przepracowania przez historyków reprezentujących inne punkty widzenia, różne narodowości, odmienne kultury, a zwłaszcza znajdujących się po dwóch stronach barykady w sporach postkolonialnych. Istnieje niemało publikacji na te tematy i zadaniem domowym płynącym z postkolonialnej lekcji uważności dla nas wszystkich jest zapoznawanie się z wynikami badań dotyczącymi trwających do dzisiaj skutków dominacji kolonialnej. Historycy, oprócz obliczeń, mają przede wszystkim za zadanie nazwać w takim stopniu, w jakim się da, rzetelnie i uczciwie, procesy oraz uczestników dawnego i nowego kolonializmu.

Natomiast zadaniem historyków literatury jest dostrzeżenie i analiza tych dzieł literackich, które próbują wyrazić, jak mogło wyglądać życie kolonizowanych i kolonizujących na różnych etapach tych procesów ${ }^{14}$. Oczywiście obraz świata przedstawionego nawet $\mathrm{w}$ znakomitym utworze literackim nie może być w pełni przystawalny do rzeczywistości pozaliterackiej, ale pozwala czytelnikowi na cenne zbliżenie się do opisywanego doświadczenia, poszerzając wyobraźnię i wrażliwość na prezentowane przeżycia. A ponieważ utwory literatury postkolonialnej są ciągle jeszcze niewystarczająco dobrze poznanym i nazwanym

13 S. Parsipur, Tuba i znaczenie nocy, tłum. A. Krasnowolska, Kraków 2012, s. 7-9.

${ }_{14}$ Dobrym przykładem tego, jak osadzona mocno na danych historycznych i pogłębiona portretami psychologicznymi literatura postkolonialna bierze pod lupę właśnie jednych i drugich, kolonizujących i kolonizowanych, w zrównoważonej reprezentacji, żadnej strony nie idealizując ani nie demonizując, przedstawia obraz tamtego świata już u samych początków procesu kolonialnego w Nowej Anglii XVII wieku, jest krótka, świetna powieść Tony Morrison Mercy, London 2009. 
zjawiskiem w historii literatury i kultury, tym bardziej potrzebna może być pomoc w lepszym rozumieniu ich kontekstów i kodów, którymi się posługują.

\section{Funkcje literatury postkolonialnej}

Spośród różnych instrumentów, narzędzi, zaleceń, jakimi obdarzyli historyków literatury i krytyków literackich badacze kolonializmu i neokolonializmu, do szczególnie cennych należy wyczulenie na to, co zostało nazwane zawłaszczaniem reprezentacji. Powieści, na które chciałabym tutaj zwrócić uwagę, zawierają różne typy narracji, struktur, portretów postaci i wspólnot, synkretycznych obrazów tożsamości, w rozmaitych proporcjach, przeplatających się ze sobą. Różne są także ich przesłania: zapisywanie ostatnich śladów czy głosów, rysowanie mapy przyczyn i skutków dominacji kolonialnej, rozpisanych w czasie i przestrzeni (sagi wielopokoleniowe), rekonstruowanie historii, uwrażliwianie na inne doświadczenia, wierzenia, odtwarzanie różnych rodzajów wyobraźni, pokazywanie obustronności win i błędów, kolonizujących i kolonizowanych, z lepiej lub gorzej zachowanymi proporcjami. Żadna z tych książek nie jest skażona „zawłaszczeniem reprezentacji” poprzez opowieść z perspektywy sił kolonizujących, czyli „cywilizujących”, nawracających, „uszczęśliwiających”, „oczyszczających”, „modernizujących”, „demonstrujących wolę bożą i przeznaczenie", na przykład w doktrynie manifest destiny ${ }^{15}$.

Zapisywanie śladów wymieniłam jako pierwszą funkcję literatury postkolonialnej nie bez powodów, gdyż dotyczy najbardziej dramatycznie późnego momentu: zapisywania głosów ostatnich świadków, a częściej już potomków ostatnich świadków, którzy jeszcze pamiętają ginące i już nieistniejące języki i kultury ${ }^{16}$. Przykładem niejako sztandarowym jest nomen omen powieść Tracks, czyli Ślady, autorstwa Erdrich.

„We started dying before the snow, and like the snow, we continued to fall. It was surprising there were so many of us left to die" ${ }^{17}$. To jeden z najpiękniejszych i najsmutniejszych cytatów z literatury postkolonialnej (a nie jestem

15 Trzeba przyznać, że wśród tekstów charakteryzujących się zawłaszczeniem reprezentacji są takie, które powstały w dobrej wierze, na przykład ciesząca się ogromną popularnością powieść Chata Wuja Toma, napisana przez Harriet Beacher Stowe, działaczkę ruchu abolicjonistów, czynnie zaangażowaną w sprawę zniesienia niewolnictwa. Tekst ten niewątpliwie miał uwrażliwiać na straszny los przywiezionych z Afryki niewolników, ale pisany był z punktu widzenia białej społeczności amerykańskiej, z perspektywy jej religijnych przekonań, a społeczność niewolników przedstawiał przez pryzmat przynależności do chrześcijaństwa.

${ }^{16}$ Funkcji zapisywania śladów ginących kultur w literaturze postkolonialnej poświęciłam rozdział pierwszy, „Samobójstwo bizonów”, mojej książki Deportowani z życia. Nowe gtosy w narracjach literackich $i$ ich kolonialne konteksty, Kraków 2017, s. 9-152.

17 L. Erdrich, Tracks, New York 1988, s. 1. 
odosobniona w tym poglądzie, co potwierdza się za każdym razem wśród słuchaczy i czytelników, kiedy ten tekst przywołuję), jest w nim wyrażone to, co szczególnie nowe i cenne w powieści budującej niezawłaszczoną reprezentację zaginionego świata kultury na naszych oczach ginącej. Fragment ten, otwierający powieść Erdrich, inicjuje bowiem narrację zbudowaną jednocześnie na faktach i na głosach reprezentujących społeczność indiańską.

Fakty to: masowa śmiertelność w rezerwacie Turtle Mountain zimą 1912/1913, spowodowana głodem, niedożywieniem, zakaźną chorobą, na którą nie było lekarstw, a przede wszystkim załamaniem psychicznym większości członków plemienia. Do tego załamania przyczyniły się: utrata wolności i sposobu życia po ostatecznym zamknięciu w rezerwatach, zabieranie dzieci siłą do szkół z internatami, służącymi „czyszczeniu” z religii, języka i obyczajów indiańskich ${ }^{18}$, rabunkowe wycinanie lasu i niszczenie jeziora, mających ogromnie ważne sakralne znaczenie dla plemienia.

Budowanie narracji reprezentującej wspólnotę indiańską polega na łączeniu głosu chóralnego i pojedynczego, „my” zamienia się w „ja”, a potem znowu wraca „my”. To, co jest opowiedziane, przekazane jest głosem ginącego plemienia Chippewa i ostatniego żyjącego jeszcze na sposób plemienny starego Indianina, który opowiada wnuczce, żeby zapamiętała i przekazała dalej: „My girl, I saw the passing of the times you will never know" ${ }^{\prime 1}$.

Narrację prowadzą głosy dwóch postaci: Nanapush i Pauline, reprezentujących dwie odmienne postawy wobec procesu kolonizacji i nawracania. Nanapush stawia bierny, ale zdecydowany opór narzuconej wierze i aparatowi zniewolenia ekonomicznego i kulturowego. Pauline nie tylko przyjmuje nowy porządek, ale także ze wszystkich sił angażuje się po stronie zwycięzców. Obie postawy adekwatnie uprawdopodobniono psychologicznie. Nanapush wydaje się pewien swojej tożsamości indiańskiej, świadomy tego, że daje mu ona siłę i czyni tym, kim jest. Odczuwa do niej przywiązanie i żywi przekonanie, że niesione przez nią wartości i obyczaje pozwalają na lepsze życie, na radość życia i ratują świat innych istot, z którymi człowiek żył w zgodzie i w równowadze ducha i ciała. Jednocześnie jest starym doświadczonym człowiekiem, realistą i wie, że to koniec, że zwycięzcy są zbyt silni i przewrotni, a kolonizowani już zbyt osłabieni i podzieleni, a jedyne, co pozostaje, to spróbować ocalić cień ginącego świata przez powtarzaną o nim opowieść. Stąd skierowanie opowieści do wnuczki, małej jeszcze, ale bardzo bystrej dziewczynki, wnuczki „przyszywanej”, indiańskiej i to z bardzo ważnego rodu szamanów (Pillagers). Bliscy członkowie rodziny Nanapusha, żona, dzieci, zginęli, tym większe symboliczne znaczenie ma zwracanie się do Lulu, zaadoptowanej wnuczki, jako do mogącej zapewnić pamięć o plemieniu Chippewa i jego kulturze.

18 Warto jako przykład tej polityki kolonizatorów przypomnieć napis nad jedną ze szkół z internatem dla indiańskich dzieci w Pensylwanii, Carlisle: „Kill the Indian, save the man”.

${ }^{19}$ L. Erdrich, dz. cyt., s. 2. 
Pauline natomiast czyni z przyjęcia nowej wiary i nowej władzy sposób na leczenie swoich kompleksów, więcej, narzędzie zemsty za doznane lub odczuwane upokorzenia ze strony pozostałych członków plemienia żyjących jeszcze w rezerwacie. Późniejsza siostra Leopolda, bo takie imię przybiera po wstąpieniu do zakonu, była i jest, w przeciwieństwie do Nanapusha, bardzo niepewna swojej tożsamości. Przynależność do plemienia indiańskiego uwiera ją i boli, a przede wszystkim Pauline wstydzi się jej. To, że jest Metyską z domieszką krwi indiańskiej, nie wydaje się aż tak istotne, bo większość plemienia Chippewa była już dosyć silnie przemieszana z białą rasą, najpierw na terenie Kanady, z kolonizatorami francuskimi, a po przejściu na południe, do USA, także i z anglosaski$\mathrm{mi}$, niemieckim i innymi europejskimi grupami etnicznymi. Ważnym aspektem realizmu tej prozy okazuje się natomiast to, że Pauline wie, iż jest postrzegana jako Indianka, i wstydzi się tego, a nawet zaczyna brzydzić się sobą. Toksyczna opinia publiczna, dominująca wśród białych Amerykanów, zaczadziła ją na tyle, że przejęła to odczucie wstrętu i czuje je jako własne. Równie duże znaczenie dla psychiki bohaterki-narratorki mają pochodzenie klasowe Pauline, czyli przynależność do biedoty, a także historia jej rodu (obciążona patologicznymi zachowaniami i z tego powodu będąca w pogardzie). W dodatku Pauline jest opisana jako kobieta brzydka, pełna kompleksów, zawistna i zazdrosna, a temperamentalnie szukająca kontroli i dominacji. Wszystko to składa się na typ człowieka, któremu tylko nowa sytuacja i przejście na stronę silniejszych, na stronę zwycięzców, pozwoli na osiągnięcie swoich celów, czyli zemsty na tych, którzy nią pogardzali, i zmuszenia ich do przyjęcia jej w roli osoby dominującej. Przy tym, ponieważ Erdrich umie cieniować portrety i konteksty, sugeruje się w powieści, że chrześcijańska wiara Pauline jest autentyczna i żarliwa, ale dzięki pozycji, jaką uzyskuje jako zakonnica w klasztorze misyjnym, przekształca się w narzędzie dominacji, a jednocześnie jej zachowania nabierają coraz silniejszych rysów chorobliwych. Sama się zadręcza i zadręcza innych.

Wspólnie, z tych dwóch głosów narracyjnych, Nanapusha i Pauline, tkana jest opowieść o życiu w rezerwacie w latach 1912-1924.

Daty mają przypominać o realiach tamtego czasu, podkreślać realizm całości. Ponieważ Erdrich uwzględnia elementy kultury synkretycznej, w tym żywe wciąż wierzenia Indian, a ten rodzaj prozy bywa określany jako realizm magiczny, pisarka, obawiając się, że taki utwór będzie interpretowany jako częściowo baśniowy, woli zaakcentować mocniej konkret historyczny. Tak właśnie autorka tłumaczyła swe intencje w wywiadzie dla telewizji kanadyjskiej. A zatem lata 1912-1924 to dla mieszkańców rezerwatu Turtle Mountain czas, kiedy w tle powstającej kultury synkretycznej widać jeszcze ślady indiańskiego obyczaju. One się zacierają, ale są jeszcze utrwalane. Kontekst autobiograficzny jest tu też obecny, bo w tym rezerwacie żyli babcia i dziadek pisarki, a jej matka jeszcze się w nim urodziła i tam spędziła dzieciństwo.

Erdrich (jej matka wywodziła się z Indian Chippewa, ojciec był emigrantem z Niemiec) jest jedną z najwybitniejszych pisarek amerykańskich przełomu 
XX i XXI wieku, wpisujących się w nurt Native American Renaissance, o czym świadczą między innymi przyznawane jej nagrody literackie, z których najważniejszą, National Book Award, przyznano jej za powieść The Round House (2012). W nurcie postkolonialnym jej powieści są wyjątkowe, bo wyróżniają się obiektywizmem w pokazywaniu przedstawicieli obu stron konfliktu. Indianie, Metysi i Biali w jej prozie to ludzie nacechowani zarówno pozytywnie, jak i negatywnie, obarczeni winą i błędami. Utwory Erdrich uderzają jakością i oryginalnością literackiej konstrukcji i języka.

\section{Reprezentacja odzyskana}

Oryginalność języka polega między innymi na połączeniu literackiego języka angielskiego ze słowami w języku Indian Chippewa/Michif wtrącanych w opowiadaniu Nanapusha i użytych w nazwach każdego rozdziału. Słowa zapisane są łacińskim alfabetem i przetłumaczone na angielski, dzięki czemu otrzymujemy ich ślad fonetyczny (zapis sugeruje wymowę) i znaczenie, a razem ze znaczeniem przynajmniej pasmo z innego sposobu tkania obrazu świata, a więc zarówno widzenia, jak i doświadczania go odmiennie. Pory roku i miesiące są więc nazwane w języku angielskim, kolonizującym, i w języku Indian Chippewa, kolonizowanym („Summer 1913, Miskomini-geezis, Raspberry Sun”, „Fall 1913 - Spring 1914 Onaubin - geezis, Crust on the Snow Sun") ${ }^{20}$, a czytelnik ma możliwość zbliżenia się do synkretycznej kultury, takiej jaka jeszcze była, a gdzieniegdzie jeszcze jest obecna, i do tego, co w badaniach postkolonialnych nazwane zostało „trzecią przestrzenią”, czyli obszarem tworzenia kultury, który nie przynależy ani tylko do kolonizujących, ani wyłącznie do kolonizowanych, ale staje się integralnie łączącą elementy obu kultur nową przestrzenią. Tak powstaje nowa jakość wyrażania siebie, siebie unikatowego, choćby częściowo stopionego z postkolonialnego konglomeratu miłości i nienawiści, ale jedynego w swoim rodzaju.

Poszukując tego, co nowe i wartościowe w pisarstwie postkolonialnym, trafiamy także na ciekawe przykłady twórczości rozwijającej się w Afryce ostatnich dekad. Analogiczna do tej użytej w powieści Erdrich metoda konstrukcji językowej pojawia się w powieści La saison de l’ombre ${ }^{21}$ kameruńskiej pisarki Leonory Miano. 90\% tekstu zapisano w języku francuskim literacko wysmakowanym, momentami zbliżonym do prozy poetyckiej, bogatej w metaforyczne określenia i subtelne gry słowne, a około $10 \%$ to słowa w jednym z języków Kamerunu, rodzimym języku pisarki, czyli douala (duala). Na końcu powieści zamieszczono słowniczek, w którym czytelnik może sprawdzić sobie znaczenia

20 Tamże, s. 11, 32.

21 Na razie nieprzetłumaczona na polski, roboczo proponuję przekład tytułu: Czas mroku. 
podane po francusku. Możemy się dowiedzieć, że określenie „dobranoc” w douala to „Niech ciemność będzie dla Ciebie dobra” (tłum. moje - K.M.B) ${ }^{22}$, a na słońce istnieją cztery słowa używane zależnie od pory dnia, a więc innej pozycji i siły słońca: Etume, Ntindi, Esama, Enange ${ }^{23}$. Tym samym nie tylko odsłania się rąbek semantycznej tajemnicy nieznanego języka, ale także, co chyba ważniejsze, inny sposób odczuwania, widzenia, nazywania swoich doświadczeń. Tak oto inna kultura uzyskuje dla siebie „namacalne” miejsce. To samo w sobie jest czymś pozytywnym, ale w wypadku kultury, której w ogóle odmawiano takiego miana, a reprezentujących ją mieszkańców Afryki traktowano jak rodzaj podludzi, obecność choćby okruchów, ale jakże sugestywnych, tego języka jest czymś fantastycznym i parę pokoleń temu jeszcze niewyobrażalnym.

Inną analogią między powieściami Erdrich i Miano jest konstrukcja narracji i zastosowanego kodu przekazywania pamięci o dramatycznych wydarzeniach przyszłym pokoleniom przez splecioną z wielu głosów opowieść plemienia. Co prawda u Miano występuje narrator trzecioosobowy, wszechwiedzący i organizujący całość, ale przemawia wyraźnie w imieniu grupy kobiet, nazywanych „tymi, których synowie nie zostali odnalezieni” ${ }^{24}$ (tłum. moje - K.M.B.). Mają one w pewnym sensie status chóru, a nazwa powraca jak refren, mantra, jak wers mnemotechniczny. $\mathrm{Z}$ tego chóru wyróżnione są następnie pojedyncze głosy, należące do różnych postaci, a każda opowiada swoją historię, ale ich doświadczenie utraty: synów, mężów, braci, porwanych i uprowadzonych w niewolnictwo, jest podobne. Innym refrenem, który powtarza się wielokrotnie w powieści, jest zawołanie szczepu Mulongo, podkreślające poczucie przynależności plemiennej jako jądra tożsamości każdej jednostki, osoby: "Jestem, dlatego że my jesteśmy/ Je suis parceque nous Sommes"25 (tłum. moje K.M.B.). Refreniczna powtarzalność tego zawołania też nadaje całości charakter wielogłosu, tak ważnego dla narracji postkolonialnej, odtwarzającej historię rodu, plemienia, szczepu, narodu, który mógł ocalić pamięć o sobie tylko poprzez wspólną opowieść. Chóralny aspekt przypomina też o charakterze oralnym wielu kultur poddanych dominacji kolonialnej. Oratura, która istniała już przed nadejściem kolonializmu, była też najlepszym ratunkiem przed unicestwieniem historii danej kultury w miejscach poddanych barbarii kolonialnej.

Najbardziej oryginalne w narracji o porwaniu w niewolnictwo zawartej w powieści kameruńskiej pisarki jest całkowite odwrócenie perspektywy. Większość powieści osnutych wokół losów niewolników przywiezionych do Ameryki czy na Karaiby pisanych jest z punktu widzenia afroamerykańskiego, natomiast w La Saison de L'Ombre (Czasie mroku) cała historia przekazywana jest

${ }^{22}$ W oryginale „Que l'obscurite te soit bonne”, por. L. Miano, La saison de l'ombre, Paris 2013 , s. 101 .

${ }_{23}$ Tamże, s. 17.

24 Tamże, s. 29.

25 Tamże, s. 94. 
z perspektywy kobiet afrykańskich, którym odebrano najbliższe im osoby. Bohaterem jest właściwie cała wioska niejako osierocona, w której zostają kobiety, dzieci i starcy, gdyż wszyscy zdolni do pracy mężczyźni, młodzi lub w średnim wieku, znikają w nocy. Zbrodnia porywania i niewola widziane tu są przede wszystkim oczami tych, którzy zostali. Zostali z bólem i tęsknotą, a także bardzo konkretnie bezbronni i pozbawieni najcenniejszych rąk do pracy, co tym bardziej dramatyczne, że ich system żywienia się i przeżycia funkcjonował dzięki pracy zbiorowej wszystkich mieszkańców wioski. Poprzez bardzo dobrze skonstruowaną zagadkę ich zniknięcia czytelnik przeżywa razem z przerażonymi kobietami ten grom z jasnego nieba, kiedy bohaterki-narratorki budzą się w na pół opustoszałej wiosce i nikt nie wie, jak to się stało, że nie ma już ich synów, mężów, ojców i braci.

Zagadka wyjaśnia się bardzo powoli, między innymi dlatego, że Rada Starców wioski zamyka „zarażone” nieszczęściem kobiety, jak zadżumione, do jednej dużej chaty, skąd nie mogą wyjść, co opóźnia bardzo wyprawę w poszukiwaniu zaginionych. Ten rodzaj magicznego myślenia jest, niestety bardzo realistycznym aspektem przedstawienia myślenia zgodnego z mentalnością animistyczną w Afryce. Powieść umocowana jest historycznie w początkach ery porywania przedstawicieli ludności afrykańskiej i sprzedawania ich, w tym wypadku Portugalczykom; sądząc z pewnych szczegółów obecnych w powieści, byłyby to wieki XVI i XVII. To zamknięcie kobiet, „ukaranie” ich odosobnieniem, pomnaża jeszcze ich cierpienie, przerażenie, poczucie krzywdy i znacznie pogarsza ich sytuację. Powoli mocniejszym z nich udaje się przekonać resztę do działania, dosłownie fizycznie wspierają się wzajemnie, jedne o drugie, pokonują strach, przedostają się przez złowrogą strefę cienia-mroku „wiszącego" u wejścia chaty i wychodzą na wolność. Niestety taka solidarność jest tylko chwilowa. Każda z kobiet jest odosobniona, z trudem udaje się zorganizować współdziałanie tylko dwóch z nich, zasadniczo pozostałe nie robią nic, sparaliżowane lękiem, samotnością, depresją. Obraz spustoszenia i nieszczęścia jest porażający i koncentruje się w pierwszej części powieści bardziej na losie tych, co zostają, niż na historii porwanych, choć echa ich głosów są oczywiście też słyszane, przede wszystkim przez kobiety, które o nich myślą, tęsknią za nimi, martwią się o nich i odczytują ich wołania we śnie.

Tajemnica zniknięcia mężczyzn z wioski z klanu Mulongo wyjaśnia się powoli, ale całkowicie. Obciążeni winą są wcale nie tylko biali, choć to oni odpowiadają za ostatnie stadium: kupienie złapanych mieszkańców wioski i załadowanie na statki odwożące ich przez ocean do Ameryki lub na Karaiby na niewolniczą katorgę. Niektórzy nigdy tam zresztą nie dopłyną, bo dziewięcioosobowej grupie z plemienia Mulongo udaje się popełnić samobójstwo, choć w ich rozumieniu jest to próba powrotu do domu, w innej postaci. Natomiast, żeby sprzedać portugalskim handlarzom spętanych i zastraszonych mężczyzn $\mathrm{z}$ interioru, do którego na tym etapie kolonizatorzy jeszcze się nie zapuszczali, ktoś musiał najpierw ich porwać i siłą przeprowadzić pod strażą przez dżunglę 
na wybrzeże, a trzeba było często pokonywać dużą odległość. Mieszkańcy wioski z głębi kontynentu nie tylko nigdy nie widzieli oceanu czy morza, nie mogli sobie nawet wyobrazić rzeki, gdyż tam, gdzie żyli, jedynym ciekiem wodnym był niewielki strumień. Kiedy kobiety słyszą w swoich snach strzępy głosów swoich synów i powtarza się relacja o ogromnej ilości wody, na której znajdują się porwani, nie mogą sobie nawet wyobrazić, czym może być taka przestrzeń. Znalezienie się w tej obcej im przestrzeni wodnej, ale, co ważniejsze, zamienienie w niewolników, zawdzięczają mężczyźni Mulongo swoim afrykańskim braciom z plemienia Bwele i drugiego potężnego plemienia z wybrzeża, Isedu. Wojownicy Bwele na rozkaz swojej królowej napadli na wioskę swoich sąsiadów Mulongo. W nocy podpalili chaty, a uciekających przed ogniem łapali w specjalnie przygotowane sieci zrzucane z drzew. Mieli też gotowe swego rodzaju „uprzęże”, „dyby” drewniane, które zakładali na pojmanych i prowadzili ich, głównie nocami, na wybrzeże, a tam odsprzedawali ich drugiej potężnej grupie plemiennej, ich wodzowi, nazywanemu w powieści księciem, który od dawna prowadził handel z "ludźmi o stopach kur” (tak ze względu na skojarzenie skórzanych butów noszonych przez portugalskich żeglarzy i żołnierzy z nogami kur określali ich mieszkańcy tej części Afryki).

Dzięki takiemu handlowi plemię Isedu, jego wyższe warstwy, czyli rządzący i jego dwór, jego żołnierze, byli bogatsi, mieli broń palną, a ich kobiety ubierały się $\mathrm{w}$ szykowne stroje szyte $\mathrm{z}$ tkanin, jakich nikt $\mathrm{z}$ innych plemion nie nosił. Duma Isedu z osiągniętych korzyści jest w powieści Miano wyraźnie zasygnalizowana ${ }^{26}$. Tym samym pisarka nazywa po imieniu współwinę niektórych Afrykańczyków w handlu niewolnikami. Przed napisaniem powieści Miano oprócz studiów w Paryżu prowadziła badania w archiwach w Senegalu i w Beninie, żeby jak najwięcej dowiedzieć się o faktach z historii niewolnictwa, także i tych mniej znanych, dotyczących współudziału Afrykańczyków odnoszących korzyści z części tej procedury ${ }^{27}$.

Zaiste nie znaczy to, że Miano czy inni, którzy o tym piszą, w jakikolwiek sposób usprawiedliwiają czyny białych kolonizatorów czy handlarzy albo umniejszają ich odpowiedzialność za zbrodnie na mieszkańcach Afryki. Jak na razie jednak nieliczni są badacze czy pisarze afrykańscy, którzy mają odwagę uzupełniać obraz tej historii o istniejącą też współwinę niektórych Afrykańczyków ${ }^{28}$.

Oprócz powieści La Saison de l'Ombre Miano jest też autorką ważnego eseju Sub-Saharan Literatures and the Conquest of the Self, w którym wprost apeluje o rozliczenie się moralne $\mathrm{z}$ historią kolonializmu i handlu niewolnikami,

${ }^{26}$ Ciekawym aspektem współwiny Afrykańczyków w handlu niewolnikami jest to, że porwanych i przemocą doprowadzonych na wybrzeże czarnych braci niejako przebierali za jeńców wojennych, goląc im głowy, z czego wynika, że byli świadomi, iż jest czymś haniebnym sprzedawanie ich, jeśli nie byli łupem wojny.

${ }^{27}$ Dane o współwinie Afrykańczyków w handlu swoimi braćmi znajdziemy między innymi w książce Jamesa Campbella, dz. cyt.

${ }^{28}$ Jedną z nich jest Yaa Gyasi w powieści Homegoing, London 2016. 
a konkretnie przyznanie się do współwiny w handlu niewolnikami ${ }^{29}$. Kameruńska pisarka widzi zresztą tę problematykę nie tylko od strony moralnej, ale także psychologicznej.

\section{Warianty realizmu i (auto)ironii}

Miano jest jednak przede wszystkim wspaniałą twórczynią literatury, wróćmy zatem jeszcze na moment do potęgi jej tekstu, czyli siły wyrazu i urody języka oraz sposobu konstrukcji jej świata przedstawionego. Oto dwa cytaty:

La nuit tombe d'un coup, comme un fruit trop mur. Elle s'ecrase sur le marais, la riviere, les cases sur pilotis. La nuit a une texture: celle de la pulpe du kasimangolo, dont on ne peut savourer toute la douceur sucree qu'en sucant prudemment les piquants du noyau ${ }^{30}$.

[Noc spada nagle jak przejrzały owoc. Rozgniata się na mokradłach, na rzece, na domach stojących na palach. Noc ma swoją gęstość: gęstość miąższu owocu kasimangolo, którego słodycz można smakować, tylko ostrożnie ssąc kolce pestki (tłum. moje - K.M.B.)].

Ce qui n'etait pas dans les recits, parce que cela ne se raconte pas, ce sont les regards debordants de detresse. (...) La parole ne permettait pas non plus de se representer les chaines. C'est la premiere fois qu'elle en voit ${ }^{31}$.

[To, czego nie było w opowieściach, dlatego, że nie da się tego opisać, to spojrzenia przepełnione rozpaczą. (...) Język nie pozwalał jej też opisać łańcuchów. Widziała je po raz pierwszy w życiu (tłum. moje - K.M.B.)].

Pierwszy cytat przywołuję tu, żeby mogła wybrzmieć choć we fragmencie proza kameruńskiej powieściopisarki. Jest $\mathrm{w}$ tym tekście przede wszystkim dobry klasyczny realizm przemawiający siłą przywołanych wrażeń zmysłowych, dosłownie „ociekający sokiem”, są gesty, mowa o gęstości tkaniny nocy, o słodyczy owocu, którą trzeba wyssać ostrożnie z kolców pestki. Widać też egzotykę nieznanego dla nas owocu o melodyjnej nazwie „kasimangolo” i koloryt lokalny, specyfikę typowego dla Afryki błyskawicznie zapadającego zmierzchu, a raczej braku zmierzchu, ponieważ słońce „spada” w jednej chwili. Wspomniane porównanie słońca do spadającego zbyt dojrzałego owocu nadaje tej prozie urodę poetycką, a wszystkie te elementy razem, proza poetycka i soczysty realizm, składają się na niezwykłą urodę tej literatury.

\footnotetext{
${ }^{29}$ L. Miano, Sub-Saharan Literatures and the Conquest of the Self, dz. cyt.

30 Taż, La saison de l'ombre, dz. cyt., s. 134-135.

31 Tamże, s. 223.
} 
W drugim cytacie chciałabym zwrócić uwagę na obecność swego rodzaju autoironii i mądrego dystansu do potęgi słowa, którą autorka skądinąd potrafi wydobyć. Opisując bardzo szczegółowo i z wrażliwością obraz widziany przez jedną z bohaterek, autorka jednocześnie podkreśla granicę, wobec której słowo jest bezsilne. Eyabe, jedna z najważniejszych i najsilniejszych postaci kobiet, jedyna, która dociera nad brzeg oceanu i ogląda scenę wprowadzania niewolników na statek, konfrontuje to, co widzi, z tym, co jej opowiadano. Przybliża nam swoje wrażenia, a najmocniej zaznacza to, czego nie da się opisać. W pierwszym zdaniu drugiego z wymienionych fragmentów konstatuje, że nie sposób przedstawić wzroku, wyrazu oczu, pełnych smutku i rozpaczy, tych, którzy zostali przemocą zmienieni w niewolników. Później mówi o bezsilności języka wobec bardzo konkretnej, materialnej rzeczy, wydawałoby się prostej, jaką są łańcuchy skuwające uprowadzonych mężczyzn. W jednym wypadku ograniczenie mocy słowa dotyczy rzeczywiście czegoś nieuchwytnego, choć bardzo realnego, czyli wyrazu oczu, w drugim czegoś bardzo właśnie materialnie namacalnego, a trudnego do określenia tylko dlatego, że wyroby z metalu były dla jej plemienia czymś nieznanym (może tylko tego rodzaju okrągłe wyroby?).

Tak czy inaczej w obu cytowanych fragmentach mamy do czynienia z literaturą wielkiej urody, ale też wysokiej próby intelektualnej, kwestionującej niejako samą siebie, poprzez obecność dyskretnie zastosowanej autoironii. A paradoksalnie przez zwrócenie uwagi na to, jak niewyrażalne słowami bywają obrazy, odczucia, zjawiska, a nawet rzeczy, pisarka osiąga efekt tym silniejszego wrażenia, jakie robi na nas opis całej sceny.

Spośród różnych możliwych metod analizowania i interpretacji literatury postkolonialnej, jej przybliżania, wybieram w moim eseju perspektywę, która kieruje czytelnika ku uważności etycznej wobec kontekstu kolonialnego i zwraca uwagę na innowacyjne sposoby narracji przez wykorzystywanie wielogłosu pozwalającego zapisywać pamięć o odchodzących już formach kultury, o doświadczeniach ginących wspólnot.

W tym celu podzielę się jeszcze jednym bardzo oryginalnym przykładem literatury postkolonialnej, mogącym być świetną lekcją uważności szczególnie dla tych, którzy potrzeby takiej uważności nie są w pełni świadomi.

Wanting (w polskim przekładzie Macieja Świerkockiego Pragnienie) Richarda Flanagana pozwoli nam też uzupełnić mapę rozważań postkolonialnych o jeszcze jeden kontynent i jego otoczenie, czyli okolice Australii, a konkretnie: Tasmanię.

Najpierw słów parę o kontekstach historycznych. Tasmania, nazywana też przez długi czas Ziemią Van Diemena, jest wyspą, choć była kiedyś częścią kontynentu Australii, zamieszkałą od około 40000 lat przez ludzi, którzy przetrwali tam dwie epoki lodowcowe, powstanie wyspy (przez odłączenie się półwyspu od stałego lądu) i kto wie, ile jeszcze innych zdarzeń czy zjawisk przyrodniczych, dopóki, na ich nieszczęście, nie wylądowali na niej biali, Europejczycy. Aborygeni wytrwali te dziesiątki tysięcy lat, żywiąc się zbieranymi 
roślinami, owocami, polując i łowiąc, żyjąc $\mathrm{w}$ równowadze z otaczającym ich światem i naturą. Tak jak na sąsiadującym z wyspą kontynencie tamtejsi Aborygeni, byli nomadami - przemieszczali się w zimie ku środkowi wyspy, a latem na wybrzeże, znowu w harmonii z panującym klimatem i otoczeniem ${ }^{32}$.

Niestety dla rdzennych mieszkańców żądni nowych zdobyczy Europejczycy najpierw powoli, tylko na obrzeżach wyspy (na początku nawet nie wiedzieli, że to wyspa), potem coraz śmielej i szybciej przywłaszczyli sobie także i to terytorium. Pierwsi byli Holendrzy (połowa XVII wieku), stąd nazwa Tasmania i Ziemia Van Diemena. Van Diemen był zwierzchnikiem Abla Tasmana, którego wysłał na poszukiwania nieznanego lądu na południe od Indonezji i Filipin, a na wschód od Afryki. Potem osady portowe zaczęli zakładać Francuzi, coraz częściej zaglądali tam też wywodzący się z różnych krajów wielorybnicy i łowcy fok, ale nie zapuszczali się w głąb lądu, a szkody czynili na morzu, systematycznie wyniszczając populację wielkich i mniejszych ssaków wodnych.

Natomiast kolonizacji całego terytorium Tasmanii dokonali Brytyjczycy. Zawłaszczanie Ziemi Van Diemena trwało od końca XVIII wieku, a w najostrzejszą fazę wkroczyło w pierwszych czterech dekadach XIX wieku, kiedy Tasmania stała się główną kolonią karną Wielkiej Brytanii i doszło do eksterminacji żyjących tam dotąd Aborygenów.

Kiedy pod koniec XVIII i na początku XIX wieku więzienia w Anglii pękały w szwach ${ }^{33}$, a terytoria na obszarze Ameryki Północnej przestały już być częścią Wielkiej Brytanii, zaczęto używać nowo zdobytą Ziemię Van Diemena jako sporą przestrzeń dla angielskich zakładów karnych. Stało się też oczywiste, że kolonizatorzy zamierzali przejąć we władanie całą wyspę i wyeliminować wszystko i wszystkich, którzy mogli im w tym przeszkadzać. Miała to być ziemia dla angielskich osadników, wspomaganych w ciężkiej fizycznej pracy przez skazańców ${ }^{34}$. Zdesperowani już wtedy tubylcy zaczęli się bronić i w rezultacie tak zwanej czarnej wojny (1824-1831) i masowego zapadania na śmiertelne dla nich choroby, którymi zarażali ich biali osadnicy, żołnierze i marynarze, Aborygeni tasmańscy zostali właściwie doprowadzeni do wymarcia. Niedobitków wywieziono siłą na pomniejsze okoliczne wyspy. Dotychczasowe badania i obliczenia historyków dotyczące okresu pierwszej połowy XIX wieku nie dają jednoznacznej odpowiedzi, ilu Aborygenów z Tasmanii zginęło od kul kolonizatorów, ilu z osłabienia i głodu po utracie swoich terenów łowieckich, a ilu z powodu chorób zakaźnych, na które nie mieli odporności. Jedno, niestety, jest pewne - plemiona zamieszkujące Tasmanię, które żyły tam przez 40000

32 Właśnie to wędrowanie i nieposiadanie aktów prawnych potwierdzających na piśmie własność ziemi wykorzystali kolonizatorzy brytyjscy jako dowód, że ziemia nie należy do tubylców, a najeźdźcy sami sobie takie akty prawne zaraz wystawili.

${ }^{33}$ A trudno się dziwić, że tak było, skoro odpowiedzialność karna w Anglii w tym czasie zaczynała się od lat siedmiu, a karane były drastycznie nawet drobne kradzieże.

34 Skazańcy nie byli wcale zawsze kryminalistami, spora ich część to więźniowie polityczni walczący o niepodległość Irlandii. 
lat, nie przetrwały kolonizacji białych najeźdźców. Bardzo, bardzo nieliczne wyjątki potwierdzały tylko tę regułę. A przerażające tempo, w jakim doszło do zagłady rdzennych mieszkańców Ziemi Van Diemena, bywa nazywane najbardziej błyskawicznym ludobójstwem, spośród tych znanych w XIX wieku ${ }^{35}$.

Powieść Flanagana Wanting zbudowana jest wokół wyżej wymienionych zdarzeń; pojawiają się daty (1821, 1830, 1856 etc.) i postacie historyczne (odnotowane w dokumentach i te funkcjonujące w przekazach ustnych, w fotografii i w malarstwie $\left.{ }^{36}\right)$. Spośród postaci historycznych trzeba wymienić jako kluczowe w konstrukcji fabuły i świata przedstawionego następujące osoby: George Augustus Robinson (w powieści zwany Protektorem), sir John Franklin (gubernator Ziemi Van Diemena i uczestnik wypraw arktycznych), jego żona lady Jane Franklin, Charles Dickens, pisarz, a spośród postaci funkcjonujących w opowieściach lokalnych - Mathinnę, aborygeńską dziewczynkę, jej ojca Towterera (przez Protektora, który nadawał swoim „podopiecznym” europejskie imiona w ramach cywilizowania, nazwany Romeo), króla ginącego plemienia. Są też inne postacie historyczne i fikcyjne, drugorzędne. Powieść jest głęboko realistyczną fikcją literacką, mocno uwzględniającą czynniki psychologiczne, socjologiczne, także kontekst historii idei, które jednocześnie ironicznie kwestionuje.

Fabuła, portrety postaci, zderzone ze sobą sytuacje i ich opisy lub towarzyszące im komentarze tworzą złożony obraz świata znajdującego się w trakcie procesu kolonizacyjnego. Całość problematyki zorganizowana jest wokół takich pojęć i zagadnień jak:

- dzikus/dzikość, cywilizacja, kanibalizm,

- edukacja oparta na rozumowym poznaniu, ćwiczeniu się w dyscyplinie i podporządkowaniu hierarchii społecznej kontra - przygotowanie do życia przez uwrażliwienie na współgranie ciała, zmysłów, spontanicznych emocji w równowadze ze współdziałaniem społecznym, grupowym i z naturą,

- nawracanie na religię chrześcijańską, postawy autentycznie chrześcijańskie i działania antyewangeliczne kolonizatorów,

- przemoc.

Jak już wspomniałam, powieść ironicznie kwestionuje przyjęte przez większość w dyskursie społecznym owego czasu (a często praktykowane jeszcze i dzisiaj) sposoby rozumienia opozycji dzikość-cywilizacja. Ta ironia budowana jest na wiele sposobów, ale jednym z najbardziej oryginalnych jest odsłonięcie

35 Dane na ten temat znajdujemy między innymi u Normana Daviesa w książce Beneath another Sky. A Global Journey into History (w polskim przekładzie Elżbiety Tabakowskiej $\mathrm{Na}$ krańce Świata. Podróż historyka przez historię, Kraków 2017) oraz w publikacjach Toma Lawsona: w studium The Last Man. A British Genocide in Tasmania, London 2014 oraz w artykule The British Genocide in Tasmania, „History Today” 2014, t. 64 (7).

${ }^{36}$ Inspiracją do stworzenia literackiej postaci Mathinny mógł być portret aborygeńskiej dziewczynki w czerwonej sukience. 
faktów dotyczących kanibalizmu, który, co bardzo prawdopodobne, miał miejsce w czasie jednej z wypraw arktycznych białych Europejczyków, wśród których był Franklin. Poznajemy go w powieści jako gubernatora Tasmanii, okrytego sławą wybitnego podróżnika i odkrywcę nieznanych terytoriów Ameryki Północnej. Z danych historycznych wiadomo, że wyrusza na tę ostatnią tragiczną wyprawę, z której już nie wróci, trzy lata po powrocie z Tasmanii. To właśnie w czasie tej ekspedycji dojdzie do tragedii, wszyscy jej uczestnicy zginą. Oba statki ugrzęzną w lodowej pułapce, część załogi zginie z chorób i osłabienia, a kiedy wyczerpią się już wszystkie zapasy, pozostali zdołają jeszcze opuścić statek, ale niektórzy umrą w czasie forsownego marszu, a inni padną ofiarą kanibalizmu. Tyle historia. Tyle podstawowe fakty. Do tego dochodzi nigdy niewyjaśniona makabryczna tajemnica: kto zjadał, a kto został zjedzony, i czy Franklin brał udział w tym ostatnim tragicznym akcie. Mówił o tym i dysputował cały ówczesny Londyn. Odbyło się wiele dramatycznych prób odnalezienia załogi lub choćby pozostałych szczątków. Wówczas nie udało się nikogo i niczego znaleźć, bardzo ciekawe odkrycia w tej sprawie nastąpiły 150 lat później. W każdym razie pisarz inspirujący się tymi faktami mógł liczyć na to, że większość jego czytelników chociaż raz słyszała o tej strasznej historii, a także o cieniu grozy i hańby, jaki padł na dowódcę całej wyprawy - Franklina.

Totalne potępienie kanibalizmu było i jest uznawane w powszechnej opinii za jeden z wyznaczników cywilizacji. Oskarżeni o wzięcie udziału w takim incydencie, jaki miał miejsce w czasie fatalnej wyprawy, do świata cywilizowanego należeć nie mogą.

To wystarczyło autorowi Pragnienia, żeby zbudować w powieści strukturę ironiczną, ze zderzenia postaci powszechnie podziwianego wielkiego podróżnika i odkrywcy, spełniającego misję cywilizacyjną wśród tasmańskich dzikusów, z mroczną historią jego zamieszania w kanibalizm podczas arktycznej wyprawy angielskich eksploratorów. Flanagan pozwolił sobie na zastosowanie niejako proroczej funkcji literatury, gdyż historycznie Franklin dopiero po pobycie na Tasmanii wyruszy w swoją ostatnią arktyczną podróż i tam być może w sytuacji ekstremalnej stanie się dzikim ludożercą. Nie zmienia to istoty przesłania. Nikt nie wie, jak zachowa się w sytuacji skrajnego zagrożenia życia, a formowanie obrazu swojej tożsamości rasowej i kulturowej jako wyższej prowadzi najczęściej nie tylko do fałszywej reprezentacji, ale także do destrukcji kultur stojących rzekomo niżej.

W powieści sugestię, że okryty sławą podróżnik i odkrywca mógł być winien kanibalizmu, neguje Lady Jane Franklin. Po jego śmierci wdowa montuje całą ogromną konstrukcję propagandową, posługując się fikcją teatralną - z pomocą Charlesa Dickensa ${ }^{37}$, którego udaje jej się namówić do współpracy, przekonuje

37 Chodzi o dramat zatytułowany The Frozen Deep (1856), którego autorami byli Wilkie Collins i Charles Dickens. 
opinię publiczną, że prawdą było przemyślnie skonstruowane i efektownie przedstawione kłamstwo o wyjątkowej szlachetności i wręcz świętości jej męża.

John Franklin, historycznie rzecz biorąc, winny być może kanibalizmu, cywilizujący „dzikich” Tasmańczyków i na jednym z poziomów powieści pośmiertnie występujący w sztuce o heroicznym poświęceniu się dla swoich towarzyszy, a na innym jej poziomie naszkicowany jako tępawy urzędnik, pasywny i uległy wobec żony hipokryta i snob - trzeba przyznać, że całość tego portretu jest godna Williama Szekspira, zwłaszcza gdy uwzględni się złożoność realizmu psychologicznego i elementy historii w tle.

Centralnie usytuowana w konstrukcji powieści jest jednak najbardziej dramatyczna, a w końcu tragiczna, historia Mathinny, która także ironicznie kwestionuje tradycyjnie przyjętą opozycję cywilizacja kontra dzikość. To portret tasmańskiej dziewczynki, $A$ Girl in a red dress, mógł zainspirować Flanagana do stworzenia jej literackiego portretu, do wyobrażenia sobie jej historii.

Pozycja Mathinny w plemieniu jest wyjątkowa, ponieważ jej ojciec jest królem i swego rodzaju kapłanem, ogromnie szanowanym w swoim klanie i mimo że dziewczynka nie ma już matki, kiedy umiera jej rodzic, dalsza rodzina i reszta grupy otoczyłaby ją opieką, co wyraźnie sugeruje Robinson ${ }^{38}$, nazywany Protektorem, biały zwolennik pokojowego rozwiązania konfliktu między kolonizatorami a rdzennymi mieszkańcami. Mimo to Lady Jane upiera się przy pomyśle adopcji tej właśnie dziewczynki. Wsparta siłą pozycji męża gubernatora stawia na swoim i Mathinna zostaje zabrana ze swojej wspólnoty.

Jak każdy dobry powieściopisarz realista Flanagan cieniuje portrety psychologiczne, wprowadza cechy pozytywne, opisując sylwetkę Lady Franklin - jej tęsknota za posiadaniem dziecka jest autentyczna, jej krótkie próby okazania czułości są również prawdziwe, ale nieskuteczne, zbyt mocno przystosowała się do angielskiego i europejskiego ukrywania uczuć jako cnoty i kierowania się opanowaniem rozumowym i obyczajowym spontanicznych emocji. Sama sobie tym robi krzywdę, ale adoptowanej dziewczynce o wiele większą. Najsilniejszą motywacją działań żony gubernatora jest jednak potrzeba poczucia spełniania misji cywilizacyjnej przez edukację adoptowanej Aborygenki. Dla Lady Jane nie może być nic bardziej wzniosłego niż ucywilizowanie „dzikuski”, a dodatkowy komfort zapewnia angielskiej damie wiek dziecka, gdyż: „Z jej punktu widzenia ta mała na szczęście właściwie nie była dzieckiem, ponieważ była dzikuską, i na szczęście nie była dzikuską, bo była dzieckiem"39.

38 Por. R. Flanagan, Pragnienie, tłum. M. Świerkocki, Kraków 2017, s. 74: „A zatem ta kochana mała nie ma matki, ojca, ani żadnej rodziny? - Ma rodzinę, szanowna pani, ale nie bliską. Tubylcy podchodzą do tych spraw w sposób bardziej swobodny, a jednocześnie bardziej skomplikowany niż my. Dla nas rodzina jest jak sznur, dla nich zaś koronka. - Ale jest sierotą? - Wedle naszego rozumienia: tak - odrzekł Protektor".

39 Tamże, s. 57. 
Oderwana od swoich bliskich, od całego dotychczasowego życia, tuż po traumie strasznej śmierci ojca, dziewczynka mimo wszystko próbuje przystosować się do zaistniałej sytuacji, ale przepaść dzieląca ją od nowych „rodziców” i ich sposobu życia, myślenia, czucia, a raczej braku czucia, jest zbyt głęboka, a otaczający świat zbyt niepojęty i zimny, by mogła w nim przetrwać. Mimo że córka króla opisana jest jako wyjątkowo inteligentna, utalentowana artystycznie, o oryginalnej urodzie i wdzięku, na dłuższą metę odczuwa swoje wyalienowanie coraz silniej. Ma też swoją dumę i dosyć mocny charakter, więc kiedy nie może już wytrzymać, potrafi zdecydowanie wyrazić swój sprzeciw, a na to nie ma miejsca w zaplanowanym dla niej scenariuszu dla ,grzecznej, dobrze ułożonej angielskiej dziewczynki”. Dopóki jeszcze wierzy, że dzięki potężnej magii, jaką ewidentnie w jej odczuciu muszą dysponować jej biali opiekunowie, uda jej się jakoś przywołać i spotkać zmarłego ojca, stara się być posłuszna, ale kiedy napisane przez nią listy do ojca ${ }^{40}$ nie przynoszą rezultatów, narastają w niej rozpacz i bunt. A oto jak wygląda jej pierwszy list napisany w wieku lat siedmiu:

Kochany Ojcze, - pisała - jestem grzeczną dziewczynką. Naprawdę kocham swojego tatę. Mam lalkę i koszulkę, i haleczkę. Czytam książki, nie ptaki. Mój ojcze dziękuję tobie za sen. Przyjdź tutaj zobaczyć mi mojego ojca. Dziękuję tobie za jedzenie. Mam poobcierane nogi i buty, i pończochy i jestem bardzo zadowolona. Tyle wielkich statków. Powiedz mojemu ojcu dwa pokoje. Dziękuję tobie za miłosierdzie. Proszę cię panie proszę wróć z polowania. Jestem tutaj twoja córka. MATHINNA ${ }^{41}$.

Jedną z oryginalnych i cennych cech literatury postkolonialnej, jak wspominałam na początku tego eseju, jest próba rekonstrukcji zaginionego w rezultacie kolonizacji świata przez oddawanie głosu tym, którzy tego głosu zbyt długo nie mieli. List Mathinny jest częścią takiej próby. Można by go nazwać wyobrażeniem stanu umysłu i uczuć w momencie powstawania synkretyzmu kulturowego.

Kiedy po paru latach Franklin i jego żoną wracają do Londynu, boją się, że dziewczynka, niewystarczająco ucywilizowana, przyniesie im tam zbyt wiele wstydu, oddają ją więc do sierocińca. Najpierw jest zaspokojenie kaprysu Lady Jane, adopcja, następnie eksperyment edukacyjno-obyczajowej transformacji w opinii „rodziców” nieudany, a potem porzucenie. Drogi powrotu do prawie nieistniejącej już wspólnoty nie ma, dla Mathinny pozostają w końcu: ulica, alkoholizm, prostytucja i śmierć w wieku siedemnastu lat.

40 Por.: „usiłowała rozwiązać zagadkę swoich licznych ojców. Ta zagadka przypominała katechizm: miała sens, jeśli powtarzało się ją odpowiednio długo i nie zadawało żadnych pytań. Był bowiem Bóg Ojciec i Jego Syn Jezus, również będący kimś w rodzaju ojca, był jednak także Protektor, w którym mieszkał Duch Boga Ojca, i wreszcie Sir John, także jej ojciec, nowy miała więc wielu ojców”. Tamże, s. 123.

${ }^{41}$ Tamże. 
Dziesięć lat z życia Mathinny (od siedmiu do siedemnastu) w świecie przedstawionym powieści Flanagana można zobaczyć jako symboliczny skrót, kolonializm w kapsułce. Pojawia się tu większość kluczowych elementów: brak szacunku dla innej kultury, postawienie kolonizatora w pozycji absolutnej wyższości moralnej, religijnej, obyczajowej, a jeśli kolonizowany nie potrafi docenić łaski, jaką wyświadczają mu stojący wyżej od niego edukatorzy, użycie przemocy, pogarda dla dzikusów i ich świata, wreszcie zmuszenie do przeistoczenia się w podobne, imitujące kolonizatora stworzenie, a w razie nieudanej transformacji zniszczenie i brak możliwości powrotu do wolności i do swojego rdzennego świata.

Dobra literatura postkolonialna stara się pokazać wieloaspektowość sytuacji i różnorodność ludzi w sytuacji zderzenia kultur. Flanagan kreśli więc zarówno sylwetki tak zwanych dobrych, jak i „złych” kolonizatorów. George Augustus Robinson, wedle danych historycznych i w świecie przedstawionym powieści, miał być postacią zasadniczo pozytywną. Dobrowolnie zgłosił się na opiekuna rdzennych mieszkańców Tasmanii, mediatora między nimi a władzami kolonizującymi, wreszcie organizatora deportacji nielicznych niedobitków po czarnej wojnie (po 1831) na sąsiednie wyspy. Musiała być to niezwykle trudna misja, gdyż wiele wskazuje na to, że z jednej strony był on autentycznie bardzo zaangażowany w ratowanie tubylców, a z drugiej strony był pod bardzo silną presją władz administrujących kolonią zmuszających go, by się swoich podopiecznych pozbył. W powieści jest też wyraźna aluzja, że za deportację tubylców z Tasmanii otrzymywał korzyści finansowe od władz brytyjskich, choć jest również sugestia, że zajmując się tym, chronił ich od o wiele brutalniejszych represji. Nic dziwnego, że w powieści jego postać to osoba rozdarta między dwoma lojalnościami, rozczarowana, przeżywająca dramat. Jego największą tragedią jest to, że tubylcy ciągle umierają. Marzy, żeby ich nawrócić na chrześcijaństwo i uszczęśliwić, a nie potrafi, mimo nieustających wysiłków, nawet pomóc im przeżyć. Zaczyna wątpić w swoją misję i w to, kim jest:

Czy stał się Bogiem? Już nie był tego pewien. Tubylcy wciąż umierali. Otaczały go trupy, czaszki, raporty z sekcji zwłok, plany budowy kaplicy i cmentarza. Jego marzenia były pełne ich tańców i pieśni, piękna ich wiosek, szmeru ich rzek, wspomnień ich czułości, a jednak wciąż umierali i umierali, i nic, co robił, nie mogło tego zmienić. Ciągle umierali i umierali, a on - który żył w starym świecie i nieustannie pracował, by udoskonalić nowy dzięki cywilizacji, chrześcijaństwu i angielskim zwyczajom - był ich Protektorem, Aborygeni jednak dalej odchodzili. Jeżeli jest bogiem, to jakim? ${ }^{42}$

A jeżeli nawet ci, którzy chcieli dobrze i na swój sposób pokochali mieszkańców wyspy albo przynajmniej się do nich przywiązali, mogli tylko patrzeć,

${ }^{42}$ Tamże, s. 26. 
zrozpaczeni, jak kolonizowani umierają. Co dopiero powiedzieć o tych, którzy wcale nie chcieli ich dobra, a przyjechali tylko po to, żeby pozyskać nowe ziemie, na których mogliby się wzbogacić, albo chociaż żyć lepiej niż w swojej starej ojczyźnie. Takie postacie oczywiście też znajdujemy w powieści, a ich przedstawicielem w najgorszym chyba wariancie jest agent z Van Diemen's Land Company, który na obiedzie wydanym przez gubernatora dla grupy londyńskich inwestorów tak oto przedstawia swoje credo kolonizatora i swoje metody kształtowania relacji z tubylcami:

jeśli nie można się z nimi uporać inaczej, trzeba ich likwidować. Nie było innej drogi do zapewnienia bezpieczeństwa białym, jak tylko zniszczenie ich czarnych przeciwników. Przez kilka lat płaciliśmy nagrody za głowę Aborygenów. Dobre pieniądze. Pięć funtów od sztuki. Moim jedynym celem w tamtych heroicznych czasach było zabić ich wszystkich. - perorował dalej Kerr nad rosołem z wombata w odświeżająco szczery i miły sposób, jak uważał Sir John ${ }^{43}$.

Smutna i straszna jest nie tylko postawa samego Kerra, ale też podziw, jaki wzbudza on wśród innych Anglików, w tym samego gubernatora. Sir John przede wszystkim zazdrości mu pewności siebie, której sam nie posiada, a także specyficznego rodzaju odwagi: „, [Kerr - dop. K.M.B] odznaczał się mrożącą krew w żyłach pewnością siebie człowieka, który nie boi się odkrytych w sobie okropności” ${ }^{44}$. A do tych okropności Kerr przyznaje się z dumą:

Co do tego, że zatknąłem trzy czarne głowy na dachu swojej chaty, mogę powiedzieć tylko tyle, że ich widok działał odstraszająco na niektórych z ich towarzyszy, każąc im wspominać śmierć współziomków i pożytecznie upowszechniając przykład, jaki z nich uczyniłem ${ }^{45}$.

Powyższy cytat nie może nas chyba prowadzić nigdzie indziej jak do JĄDRA CIEMNOŚCI - zarówno symbolicznie, jak i intertekstualnie. Wracamy w ten sposób do pierwszej i najważniejszej lekcji uważności zawartej w literaturze dotyczącej kolonializmu, do powieści Josepha Conrada. Gdzieś pomiędzy Protektorem, Robinsonem, który zastanawia się, czy i jakim jest bogiem, a agentem Kerrem, mówiącym: „Jesteśmy emisariuszami Boga, nauki i sprawiedliwości”’46 i zatykającym na dachu trzy czarne głowy, musi pojawić się cień Kurtza. Co prawda Kurtz miał być może jeszcze bardziej koszmarne czyny na sumieniu, ale przynajmniej przed śmiercią przeraził się okropności, jaką w sobie w końcu zobaczył: "The Horror, the horror".

\footnotetext{
43 Tamże, s. 179.

44 Tamże, s. 181.

45 Tamże, s. 180.

46 Tamże, s. 181.
} 
Tym samym, w moim eseju, przedstawiającym wyróżniające się przykłady literatury postkolonialnej, zatoczyliśmy koło. Podsumowując analizę i interpretację powstałych stosunkowo niedawno tekstów (2013 Miano; 2008 Flanagan; 1988 Erdrich), dobrze jest rzucić okiem na początek drogi. Drogi rozumianej jako proces rozwoju literatury postkolonialnej, zwłaszcza w jej funkcji rozbudzania uważności na historię relacji kolonizujących i kolonizowanych. Jądro ciemności Conrada powstało przecież jako reakcja autora na wiadomości upublicznione w prasie przełomu XIX i XX wieku o okropnościach kolonialnych w Kongu ${ }^{47}$. A po prawie 120 latach i owszem, sporo dobrych tekstów krążących wokół tej problematyki pojawiło się, ale zaiste temat nie został wyczerpany. Od zawłaszczonej reprezentacji do reprezentacji tworzonej głosami niegdyś kolonizowanych lub z ich punktu widzenia albo, jak w powieści Wanting, do ironicznego zestawienia różnych punktów widzenia, narracje postkolonialne wzbogacają się o coraz ciekawsze konstrukcje.

\section{Aktualizacja „oprogramowania” uważności postkolonialnej}

Oczywiście, zaginione z powodu kolonializmu światy pozostaną zaginione, ale niektóre ślady językowe, mityczne, muzyczne można jeszcze rekonstruować lub odnajdywać w „trzeciej przestrzeni” kultur synkretycznych. A historię kolonializmu można ciągle uzupełniać tam, gdzie jest to najbardziej potrzebne, czyli w edukacji i w przestrzeni publicznej, medialnej.

Najgłośniej mówią o zmianach w postawie wobec byłych kolonii niektórzy politycy reprezentujący kraje byłych kolonizatorów. Zwłaszcza przed wyborami, ale też z okazji okrągłych rocznic, wypowiadają się w sposób bardzo poprawny politycznie przeciwko rasizmowi, za koniecznością wyrównywania szans dla mieszkańców byłych kolonii lub zwracają uwagę, jak bardzo należy cenić kultury rdzennych narodów i ich cnoty ekologiczne. Niestety za tymi słowami rzadko idą konkretne działania, szczególnie brakuje edukacji na temat kolonializmu w poszczególnych państwach, które na systemie kolonialnym zbudowały swoje ogromne bogactwo.

Wielką Brytanię, czyli największego swego czasu imperium kolonialnego, nie stać było nawet na gest, który mógł mieć duże znaczenie symboliczne, czyli oddanie jednego z największych diamentów (brylantów) na świecie, sławnego Kohinoor, co znaczy „Mountain of Light”, tkwiącego obecnie w koronie królowej Elżbiety II. Gdy w 2010 roku Indie zwróciły się do brytyjskiego rządu z petycją o oddanie klejnotu, spotkały się z odmową.

Mimo wszystko pewne sukcesy $\mathrm{w}$ działaniach poszczególnych grup etnicznych i stowarzyszeń na rzecz rozpowszechniania wiedzy o historii kolonializmu

47 Zob. S. Lindqvist, Wytępić cate to bydto, tłum. M. Haykowska, Warszawa 2009. 
i jego konsekwencji można odnotować, nawet jeśli na niewielką skalę. Wygrane zostały procesy o zwrot ludzkich szczątków i przedmiotów rytualnych, wytoczone przez reprezentantów paru grup plemiennych w USA i Kanadzie. Powodzeniem zakończyły się także nieliczne procesy sądowe o zwrot kawałka ziemi, ze znajdującymi się na tym terenie kopalinami. Premierzy Australii i Kanady wygłosili formalne przeprosiny za szkody fizyczne i psychiczne wyrządzone dzieciom i rodzinom rdzennych populacji z powodu przymusowej edukacji w szkołach z internatami. To krople w morzu krzywd wołających o zadośćuczynienie, ale te słowa mają znaczenie symboliczne dla tych, którzy jeszcze żyją.

A jakie są najnowsze przykłady z Europy, które potwierdzają, że coś pozytywnego dzieje się także, choćby w mikroskali, w uważności postkolonialnej? W mediach społecznościowych w Szkocji zaproponowano program uzupełniania wiadomości na temat znanych, nawet sławnych osób, których nazwiska użyte są w nazwach ulic, placów, budynków, informacją, o ile ich stan posiadania zwiększył się, a pozycja społeczna wzrosła dzięki handlowi niewolnikami, w który byli aktywnie zaangażowani. Tylko parę cyfr i słów lapidarnie informujących o tym fakcie, obok tabliczki z nazwą ulicy czy budowli „na cześć”. Analogiczna inicjatywa, choć na bardzo małą skalę, ruszyła w Belgii (Namur i Bruksela). Wszystkie pomniki Leopolda II odpowiedzialnego za zbrodnie w Kongo belgijskim pozostają jednak nadal nietknięte.

Nawet jeśli tych parę jaskółek ciągle jeszcze wiosny nie czyni, myślę o wiośnie edukacji postkolonialnej, to jednak każda lekcja uważności postkolonialnej ma swoją wartość, a zwracanie uwagi na ciekawe przykłady w światowej literaturze postkolonialnej bywa pożyteczne, choćby po to, by częściej toczył się wokół tej problematyki dialog, do czego tekst niniejszy mam nadzieję się przyczyni.

\section{Bibliografia}

\section{Teksty literackie}

Conrad J., Heart of Darkness, New York 1968.

Couto M., Ostatni lot flaminga, tłum. E. Milewska, Warszawa 2005.

Erdrich L., Tracks, New York 1988.

Flanagan R., Pragnienie, tłum. M. Świerkocki, Kraków 2017.

Gyasi Y., Homegoing, London 2016.

Miano L., La saison de l'ombre, Paris 2013.

Morrison T., A Mercy, London 2009.

Teksty historyczne, kulturoznawcze, literaturoznawcze

Ashcroft B., Griffiths G., Tiffin H., The Empire Writes Back. Theory and Practice in Post-Colonial Literatures, London-New York 1989. 
Buck-Morss S., Hegel, Haiti i historia uniwersalna, tłum. K. Bojarska, Warszawa 2014.

Campbell J.T., Middle Passages. African American Journeys to Africa, 1787-2005, London 2006.

Davies N., Na krańce świata. Podróż historyka przez historię, tłum. E. Tabakowska, Kraków 2017.

Durant W., A Case for India, New York 1930.

Lawson T., The British Genocide in Tasmania, „History Today” 2014, t. 64 (7).

Lawson T., The Last Man. The British Genocide in Tasmania, London 2014.

Lindqvist S., Wytepić cate to bydto, tłum. M. Haykowska, Warszawa 2009.

Mabanckou A., Le sanglot de l'homme noir, Paris 2012.

Miano L., Sub-Saharan Literatures and the Conquest of the Self, „Journal of the African Literature Association" 2014, t. 8 (2).

Mroczkowska-Brand K., Deportowani z życia. Nowe gtosy w narracjach literackich i ich kolonialne konteksty, Kraków 2017.

Parsipur S., Tuba i znaczenie nocy, tłum. A. Krasnowolska, Kraków 2012.

Said E., Orientalizm, tłum. M. Wyrwas-Wiśniewska, Poznań 2005.

Tharoor Sh., Inglorious Empire. What the British Did to India, London 2016.

Williams E., From Columbus to Castro. The History of the Caribbean, New York 1984. 